afterwards shown to be appreciably in error, was of considerable importance historically, since it directed attention to the necessity of examining further the result obtained in 1863 and, 1864 by Maxwell and his coadjutors for the British Association Committee on Electrical Standards.

In I87 I Kohlrausch introduced a method for measuring the electrical resistance of electrolytes founded upon the employment of alternating currents generated by the revolution of a magnet inside a coil of wire, the relative positions of magnet and coil being like those in an ordinary galvanometer. In this way the disturbing effect due to the polarisation of the electrodes was in a great measure, if not entirely, got rid of, and the results obtained were a great advance in respect of accuracy upon those previously obtained. In later modifications of the method the alternate surrents of an induction-coil were used. This investigation formed the starting point of a long series of researches into the conducting power of electrolytic solutions. The examination of a great number of soluble salts in aqueous solutions of different concentrations showed that, although the conductivity decreases with decreasing concentration, the ratio of conductivity to concentration increases, at first nearly uniformly, but approaches a definite limit for each salt when very small concentrations are reached, that is, when the solutions are very dilute. It was further found that, when the proportion of salt in solution was expressed in terms of the equivalent mass of the salt, the limiting (maximum) value of the above ratio varied within comparatively narrow limits for a great number of salts. Another important result of Kohlrausch's experiments was the establishment of a simple relation between the conductivities of dilute solutions and the mobilities, as deduced from Hittorf's measurements, of the ions into which the respective salts may be supposed to be broken up when dissolved.

Kohlrausch rendered an extremely valuable service to the teaching of experimental physics by the publication, in 1870 , of his "Leitfaden der praktischen Physik." This was the first, and, in the writer's opinion, the best of numerous works of the same kind that have since appeared in various countries, designed to guide students of physics in a systematic course of practical work in the physical laboratory. The high appreciation it has met with is shown by the number of editions that have been called for-it reached the eighth in 1896 ; it was translated into English by Messrs. T. H. Waller and H. R. Procter soon after its first appearance, and a second English edition was published in 1883 .

G. C. F.

\section{SIR CHARLES TODD, K.C.M.G., F.R.S.}

FEW men have lived a fuller life or given more freely of their best than Sir Charles Todd, whose death we deeply regret to record. It is only about three years ago that he retired from active service, but he was then above eighty years of age and his career had been unusually long. His scientific life dates back to $\mathrm{I} 84 \mathrm{I}$, when he entered the Royal Observatory, Greenwich. The instruments, as those who used them, have passed away, and he must have been the last survivor of the little band who worked with the old meridian transit and circle. There he acquired a training in scientific methods which he was destined to turn to such useful account in promoting the interests of a new colony. In South Australia he found his work, and there his memory will be treasured. For it was his fortune to organise two departments, the Post Office and the Meteorological Service, which have contributed in no small degree to the growth of that thriving settlement.

It is not given to many to see their exertions and NO. 2 IOI, VOL. 82] plans so speedily and completely successful as did Sir Charles Todd, or to fill simultaneously the three important positions of Postmaster-General, Superintendent of Telegraphs, and Government Astronomer. But it will be admitted that he filled this trinity of offices with credit to himself and to the advantage of others. The Post Office was practically his own organisation, which, continually growing with the requirements of the Colony, proved itself equal to the increasing demands. It was in connection with the establishment of the Telegraph Service, and its growing needs, that he made that remarkable ride of 2000 miles across the arid interior of the continent of Australia, from Adelaide to Port Darwen. The energy and intrepidity of the man were well illustrated by this memorable venture. No wonder that he loved to tell of that day, . when he sat on the ground near Mount Stewart, amid uncomfortable surroundings, but forgot all in the sense of successful achievement, when, with a little pocket relay, he connected the wires and held communication with the extreme north and south of the island.

As Government Astronomer, it will be remembered that Sir Charles Todd took part in organising the expeditions for the observation of the transit of Venus, that he kept the 8 -inch refractor steadily at work, and did what lay in his power to maintain an interest. in astronomy. Still greater was the service he rendered in promoting a meteorological and climatological servey-so necessary in a new country, where the climatic conditions are of vital importance to the incoming settler. For something like forty years he maintained the meteorological service, and has left to his successor a complete and well-equipped organisation.

His talents were admirably fitted for the field in which they found scope. He knew how to inspire others with the tireless energy that carried him throlygh so many difficulties; his geniality secured him many friends and willing workers that enabled him to accomplish so much; his life and history are written in the progress of the colony during the last fifty years: Amid the regrets of those among whom he laboured so well and so long, he will be remembered as one whose services gained the approval of his sovereign and the cordial appreciation of his scientific colleagues, and especially as a typical specimen of that class which, great in resolve as in achievement, has given strength and impulse to our Colonial Empire.

\section{NOTES.}

AT the meeting of the Paris Academy of Sciences on January 24 Lord Rayleigh was elected a foreign associate member in succession to the late Prof. Simon Newcomb. Lord Rayleigh was elected a correspondant of the academy in 1890.

M. Emmanuel, DE Margerie has been elected president for 1910 of the Paris Geographical Society, and M. H. Deslandres and Colonel Bourgeois vice-presidents.

DurIng his recent visit to St. Petersburg, Sir Ernest Shackleton was presented with the Constantine gold medal of the Russian Geographical Society.

The Lettsomian lectures on "The Cerebellum and its Affections" will be delivered by Dr. J. S. Risien Russell at the Medical Society of London on February 7 and 21 and March 7 .

AT the close of a public lecture by Dr. Sven Hedin in Rome on January 30 , the King of Italy handed to him the large gold medal which has been conferred upon him by the Italian Geographical Society. 